\title{
Growth and photosynthesis of Gossypium hirsutum L at high photon flux densities: effects of soil temperatures and nocturnal air temperatures
}

\author{
M Königer ${ }^{\star \star}, \mathrm{K}$ Winter * \\ Lehrstuhl für Botanik II, Julius-von-Sachs-Institut für Biowissenschaften, \\ Mittlerer Dallenbergweg 64, D-97082 Würzburg, Germany
}

(Received 10 December 1992; accepted 5 March 1993)

\begin{abstract}
Summary - Gossypium hirsutum, when grown under both medium ( $1000-1100 \mu \mathrm{mol} \mathrm{m}^{-2} \mathrm{~s}^{-1}$ ) and high photon flux densities (PFD, $1800-2000 \mu \mathrm{mol} \mathrm{m}^{-2} \mathrm{~s}^{-1}$ ) showed reduced total dry weights and total leaf areas with decreasing temperatures during the dark period $\left(25,15\right.$ or $\left.10^{\circ} \mathrm{C}\right)$, while photosynthetic capacity $\left(P S_{\max }\right)$ and quantum yield of photosynthetic $\mathrm{O}_{2}$ evolution $(\varnothing)$, as well as the light-use efficiency of photosystem II $\left(F_{\mathrm{V}} / F_{\mathrm{M}}\right)$ were not affected. Maintaining a day/night soil temperature of $25^{\circ} \mathrm{C}$ for one set of plants (high PFD, $34 \% 10{ }^{\circ} \mathrm{C}$ ) resulted in a $44 \%$ increase in total dry weight, an increase in turgor pressure, but no significant change in $P S_{\text {max }}$. During another set of experiments cotton plants were cultivated at either medium PFD and $20 / 25^{\circ} \mathrm{C}$ (day / night) air temperatures or at high PFD and either $24 / 25^{\circ} \mathrm{C}$ or $34 / 25^{\circ} \mathrm{C}$ air temperatures. The soil temperatures were maintained independent of the air temperatures at either $20^{\circ}$ or $30^{\circ} \mathrm{C}$. Cultivating the plants at a soil temperature of $30^{\circ}$ rather than $20^{\circ} \mathrm{C}$ resulted in large percentage increases in total dry weight (28-55\%), but did not have any impact on $F_{V} / F_{M}$ and the pigment content of the leaves. The importance of night and rhizosphere temperatures for plant growth and development are discussed.
\end{abstract}

Gossypium hirsutum $=$ cotton $/$ growth reduction $/$ night temperature $/$ photosynthesis $/$ soil temperature

Résumé - Croissance et photosynthèse de Gossypium hirsutum L à hautes intensités lumineuses : effets de la température du sol et de la température nocturne de l'air. Gossypium hirsutum, cultivé sous des intensités lumineuses moyennes (1 000-1 $100 \mu \mathrm{mol} \mathrm{m} \mathrm{m}^{-2} \mathrm{~s}^{-1}$ ) et hautes (PFD : $1800-2000 \mu \mathrm{mol} \mathrm{m}^{-2} \mathrm{~s}^{-1}$ ) a montré une diminution du poids sec total et des aires foliaires totales avec la baisse de températures pendant la période obscure $\left(25^{\circ} \mathrm{C}\right.$, $15^{\circ} \mathrm{C}$, ou $10^{\circ} \mathrm{C}$ ), alors que l'intensité photosynthétique ( $P S_{\max }$ ) et le rendement quantique de l'évolution de l' $\mathrm{O}_{2}$ photosynthétique (Ø), ainsi que l'efficacité dans l'utilisation de la lumière du photosystème I/ ( $\left.F_{V} / F_{M}\right)$ n'ont pas été touchés. Le maintien de la température jour/nuit du sol à $25^{\circ} \mathrm{C}$ pour un ensemble de plantes (hautes $P F D, 34 / 10^{\circ} \mathrm{C}$ ) a donné comme résultat une augmentation de $44 \%$ du poids sec total et une augmentation de la pression de turgescence, mais il n'y a pas eu de changements significatifs de la $P S_{\text {max. }}$ Pendant un autre ensemble d'expériences, des plantes de coton ont été cultivées à des PFD moyennes et des températures d'air de $20 / 25^{\circ} \mathrm{C}$ (jour/nuit) ou à des hautes PFD et à des températures d'air de $24 / 25^{\circ} \mathrm{C}$ ou $34 / 25^{\circ} \mathrm{C}$. Les températures du sol ont été maintenues indépendantes de celles de l'air à $20^{\circ} \mathrm{C}$ ou $30^{\circ} \mathrm{C}$. La culture de plantes à des températures du sol de $30^{\circ} \mathrm{C}$ plutôt qu'à $20^{\circ} \mathrm{C}$ a donné comme résultat des augmentations importantes dans le poids sec total (28-55\%), mais n'a eu aucun effet sur $F_{W} / F_{M}$ et la teneur en pigment des feuilles. L'importance des températures nocturnes et de celles de la rhizosphère pour la croissance et le développement sont discutées.

Gossypium hirsutum $=$ coton $/$ réduction de la croissance $/$ température nocturne $/$ photosynthèse $/$ température du sol

\footnotetext{
- Present address: Smithsonian Tropical Research Institute, PO Box 2072, Balboa, Republic of Panama.

** Correspondence and reprints: Smithsonian Tropical Research Institute, PO Box 2072, Balboa, Republic of Panama.

Abbreviations : Car: carotenoids; Chl: chlorophyll; DW: dry weight; $F_{\mathrm{V}} / F_{\mathrm{M}}$ : ratio of variable to maximum fluorescence yield; PFD: photon flux density (400-700 nm); $P S_{\text {max }}$ : photosynthetic capacity, maximum rate of $\mathrm{O}_{2}$ evolution measured under saturating light and $\mathrm{CO}_{2}$ conditions; specific leaf weight: dry weight per leaf area; $\varnothing$ : photon yield of photosynthesis based on absorbed light (630$700 \mathrm{~nm})$
} 


\section{INTRODUCTION}

It has become evident that temperatures which are suboptimal for photosynthesis but far above the chilling range $\left(0^{\circ}-12^{\circ} \mathrm{C}\right)$ can cause severe reductions in photosynthetic competence, especially in combination with high light intensities (Ögren et al, 1984; Greer et al, 1988; Gong and Nilsen, 1989; Rosenqvist et al, 1991; Brüggemann et al, 1992; Königer and Winter, 1992). Reducing the air temperature from $34{ }^{\circ} \mathrm{C}$ to $25{ }^{\circ} \mathrm{C}$ or $21^{\circ} \mathrm{C}$ at $1800-2000 \mu \mathrm{mol}$ photons $\mathrm{m}^{-2} \mathrm{~s}^{-1}$ resulted in marked reductions in photosynthetic capacity and growth in cotton plants (Königer and Winter, 1991; Winter and Königer, 1991).

Little is known about the effects of different temperatures during the dark period on photosynthesis and growth of plants, since in most experiments temperatures were changed simultaneously during the light and dark period (eg Downton and Slatyer, 1972; Huang et al, 1989; Schleppi et al, 1990; Zollinger and Kells, 1991). Those experiments in which the temperature during the dark period was changed independently of the light period suggested that the night temperatures might have a significant impact on plant growth. Patterson and Mortensen (1985) even concluded from their investigations on common crupina (Crupina vulgaris), that dry-matter accumulation is in general more sensitive to night temperature than to day temperature. Also the deleterious effects of low night temperatures are well known for a variety of $\mathrm{C}_{4}$ species. For example, photosynthetic rates and growth were reduced markedly in Digitaria decumbens when it was exposed to a night temperature of $10^{\circ} \mathrm{C}$ (West, 1973). Rotteboellia exaltata, another $C_{4}$ species, also exhibited significant reductions in dry weight with night temperatures $<23^{\circ} \mathrm{C}$ (Patterson et al, 1979).

Under field conditions low air temperatures inevitably lead to low soil temperatures, which itself may adversely affect plants by changing the water and nutrient uptake properties of the roots and the net translocation of carbon assimilates (Shirazi et al, 1975; Kramer, 1983; Mc Allister and Haderlie, 1985; Bassiri Rad et al, 1991).

To further extend our knowledge about temperature effects on cotton plants exposed to high light intensities (Königer and Winter, 1991; Winter and Königer, 1991; Königer and Winter, 1993) we initiated this study to investigate the effects of different air and soil temperatures on photosynthesis and the growth patterns of cotton following 2-wk treatment periods.

\section{MATERIAL AND METHODS}

\section{Cultivation of plants}

Cotton seedlings (Gossypium hirsutum $\mathrm{L}$ var Delta pine 61 , primary leaf $20 \mathrm{~cm}^{2}$, first foliar leaf $6 \mathrm{~cm}^{2}$ ) were grown for 2 wks in 18-I pots placed in controlled environment chambers as described in Winter and Königer (1991). The light intensities applied during $12 \mathrm{~h}$ photoperiods were $1000-1 \quad 100 \mu \mathrm{mol} \mathrm{m}^{-2} \mathrm{~s}^{-1}$ (medium PFD) or 1800-2 $000 \mu \mathrm{mol} \mathrm{m} \mathrm{m}^{-2} \mathrm{~s}^{-1}$ (high PFD, equivalent to full sunlight). In those experiments where the soil temperature was kept constant, the plants were cultivated in 25-I pots with waterjackets connected to a circulating waterbath.

The plants were flushed with 2 I of nutrient solution (Wong, 1979) at 2-d intervals resulting in high leaf nitrogen contents (4-5\% of dry weight).

Air temperatures (measured in close proximity to the third foliar leaf), leaf temperatures (measured at the third foliar leaf), and soil temperatures (measured $14 \mathrm{~cm}$ below the soil surface) were determined with copper-constantan thermocouples connected to $\mathrm{TH}-65$ thermometers (Wescor Inc, Logan, UT).

\section{Biomass}

At the end of the 2-wk growth periods, the plants were harvested and the leaf areas determined using an area meter (LI-3100; Li-Cor, Lincoln, NE). The dry weights of leaves, stems and roots were measured after drying for $48 \mathrm{~h}$ at $100^{\circ} \mathrm{C}$.

\section{Water relations}

Water potential $(\psi)$ and osmotic pressure $(\pi)$ were determined on leaf discs at $30^{\circ} \mathrm{C}$ according to the dewpoint method with thermocouple psychrometers (Model-52; Wescor, Logan, UT). The osmotic pressure was determined on the same discs used for water potential measurements following freezing and thawing. Turgor pressure was estimated from $\psi+\pi$.

\section{Pigment contents}

Chlorophyll and carotenoid contents of leaf discs were determined in $80 \%$ acetone according to Röbbelen (1957) including the suggested changes of Metzner et al (1965). 


\section{$\mathrm{O}_{2}$ exchange}

Photosynthetic capacities at light saturation and quantum yields from leaf discs $\left(10 \mathrm{~cm}^{2}\right)$ were determined with a Hansatech LD-2 leaf disc $\mathrm{O}_{2}$ electrode unit and a Hansatech LS-2 light source (King's Lynn, Norfolk, UK). Samples were taken at the end of the dark period of $\mathrm{d} 14$ and measured at $25^{\circ} \mathrm{C}$ and $5 \% \mathrm{CO}_{2}, 20 \% \mathrm{O}_{2}$, $7.5 \% \mathrm{~N}_{2}$. Photosynthetic capacity was measured at $1600 \mu \mathrm{mol} \mathrm{m} \mathrm{m}^{-2} \mathrm{~s}^{-1}$. The quantum yields were based on absorbed red light $(630-700 \mathrm{~nm})$. The light source was calibrated with a quantum sensor (Li-190 SB, LICor, Lincoln, NE, USA).

\section{Leaf optical properties}

Reflectances, transmittances, and absorbances (630$700 \mathrm{~nm}$ ) were determined with an integrating sphere (LI-1800-12; Li-Cor, Lincoln, NE) connected to a spectroradiometer (LI-1800; Li- Cor, Lincoln, NE).

\section{Room temperature fluorescence}

$\mathrm{Chl}_{\mathrm{a}}$ fluorescence of leaf discs, taken at the end of the dark period, was measured at room temperature using a pulse amplitude modulation fluorometer (PAM 101; Walz, Effeltrich, Germany; Schreiber et al, 1986) following the procedure described in Königer and Winter (1991).

\section{RESULTS}

\section{Effects of different air temperatures during the dark period}

Cotton seedlings were cultivated for $14 \mathrm{~d}$ at a series of different temperatures during the dark period $\left(25^{\circ}, 15^{\circ}, 10^{\circ} \mathrm{C}\right)$ and either medium or high PFD and $33^{\circ}-34^{\circ} \mathrm{C}$ during the light period. The total dry weights (shoots + roots) decreased with decreasing temperatures during the dark periods (fig 1). At night temperatures of $25^{\circ}$ and $15^{\circ} \mathrm{C}$ the high-light grown plants had somewhat higher dry weights than the low-light grown plants. At $10^{\circ} \mathrm{C}$ night temperature, the reverse was true. The reductions in total dry weight at $15^{\circ}$ or $10^{\circ} \mathrm{C}$ relative to $25^{\circ} \mathrm{C}$ were mainly due to decreases in shoot dry weight (table I). For example, when plants were grown under medium PFD and 33/ $25^{\circ} \mathrm{C}$ (light/dark period) a dry weight ratio of shoot to root of 11.6 was obtained. Reducing the temperature during the dark period to $10^{\circ} \mathrm{C}$

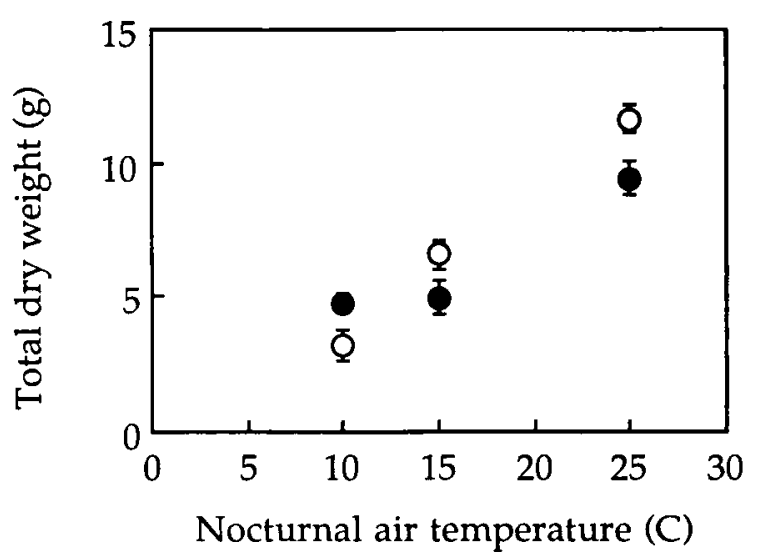

Fig 1. Total dry weight versus night temperature in Gossypium hirsutum plants, harvested after 2-wk cultivation periods under high $(\mathrm{O})$ or medium (ब) PFD and $33-34^{\circ} \mathrm{C}$ during the light periods. Data are means $\pm \mathrm{SD}(n=3)$.

throughout the 14-d treatment resulted in a shoot/root ratio of 7.0. A similar trend was seen in the high-light grown plants. The total leaf area also decreased with decreasing temperatures during the dark period for both medium and high light grown plants (table I). For example, plants grown at high PFD and $34 / 10^{\circ} \mathrm{C}$ had a $79 \%$ smaller total leaf area than those exposed to the same light intensity but $34 / 25^{\circ} \mathrm{C}$. The specific leaf weight, as well as the leaf/stem ratios, increased with decreasing temperatures during the dark period for both experimental light treatments.

The soil temperatures changed markedly during the various 24-h cycles, reaching the lowest values at the end of the respective dark periods (data not shown; see Winter and Königer, 1991). For example, cotton plants cultivated at high PFD and $34 / 10{ }^{\circ} \mathrm{C}$ experienced soil temperatures ranging between $14-30{ }^{\circ} \mathrm{C}$ during the course of $24 \mathrm{~h}$. To investigate the effect of this factor on growth and photosynthesis, the soil temperature was kept at a constant temperature at $25{ }^{\circ} \mathrm{C}$ for one set of plants (high PFD, 34/ $10^{\circ} \mathrm{C}$ ) throughout the entire 14-d growth period. Keeping the soil temperature at a constant $25^{\circ} \mathrm{C}$ resulted in total dry weight increase of $44 \%$ (table I). Total leaf area, specific leaf weight, and shoot/root dry weight ratio also increased, but the differences between the treatments were not marked.

$P S_{\max }$ expressed on an area basis was slightly higher for plants grown under high PFD than for those grown at medium PFD, but did not decrease with decreasing temperatures during the 
Table I. Growth characteristics of Gossypium hirsutum.

\begin{tabular}{|c|c|c|c|c|c|c|c|}
\hline \multirow[t]{2}{*}{ Growth characteristic } & \multicolumn{3}{|c|}{ Medium PFD } & \multicolumn{4}{|c|}{ High PFD } \\
\hline & $33 / 10^{\circ} \mathrm{C}$ & $33 / 15^{\circ} \mathrm{C}$ & $33 / 25^{\circ} \mathrm{C}$ & $\begin{array}{r}34 / 10^{\circ} \mathrm{C} \\
25^{\circ} \mathrm{C} \text { soil }\end{array}$ & $34 / 10^{\circ} \mathrm{C}$ & $34 / 15^{\circ} \mathrm{C}$ & $34 / 25^{\circ} \mathrm{C}$ \\
\hline \multicolumn{8}{|l|}{ Shoot plus roots } \\
\hline (g DW) & $4.79 \pm 0.33$ & $4.98 \pm 0.61$ & $9.42 \pm 0.65$ & $4.65 \pm 0.48$ & $3.23 \pm 0.59$ & $6.57 \pm 0.53$ & $11.64 \pm 0.55$ \\
\hline Shoot (g DW) & $4.20 \pm 0.32$ & $4.39 \pm 0.64$ & $8.46 \pm 0.63$ & $4.11 \pm 0.42$ & $2.82 \pm 0.58$ & $5.72 \pm 0.49$ & $10.71 \pm 0.48$ \\
\hline Roots (g DW) & $0.60 \pm 0.02$ & $0.59 \pm 0.06$ & $0.73 \pm 0.14$ & $0.54 \pm 0.06$ & $0.41 \pm 0.07$ & $0.85 \pm 0.08$ & $0.93 \pm 0.08$ \\
\hline Shoot/root $\left(\mathrm{g} \mathrm{g}^{-1}\right)$ & 7.00 & 7.44 & 11.6 & 7.61 & 6.88 & 6.73 & 11.50 \\
\hline Leaves (g DW) & $3.19 \pm 0.23$ & $3.24 \pm 0.52$ & $5.83 \pm 0.39$ & $3.14 \pm 0.36$ & $2.17 \pm 0.42$ & $4.33 \pm 0.36$ & $7.49 \pm 0.46$ \\
\hline Stems (g DW) & $1.00 \pm 0.09$ & $1.16 \pm 0.12$ & $2.63 \pm 0.24$ & $0.97 \pm 0.07$ & $0.64 \pm 0.17$ & $1.39 \pm 0.13$ & $3.22 \pm 0.06$ \\
\hline Leaf/stem $\left(\mathrm{g} \mathrm{g}^{-1}\right)$ & 3.19 & 2.79 & 2.22 & 3.24 & 3.39 & 3.12 & 2.33 \\
\hline $\begin{array}{l}\text { Leaf area total }\left(\mathrm{cm}^{2}\right) \\
\text { Spec leaf weight }\end{array}$ & $471 \pm 40$ & $547 \pm 87$ & $1379 \pm 119$ & $379 \pm 54$ & $311 \pm 62$ & $633 \pm 68$ & $1489 \pm 107$ \\
\hline$(\mathrm{mg} \mathrm{DW} \mathrm{cm}-2)$ & 6.77 & 5.92 & 4.23 & 8.28 & 6.98 & 6.84 & 5.03 \\
\hline
\end{tabular}

Plants were cultivated for 2 wk at $1000-1100 \mu \mathrm{mol}$ photons $\mathrm{m}^{-2} \mathrm{~s}^{-1}$ (medium PFD) and $33^{\circ} \mathrm{C}$ or at $1800-2000 \mu \mathrm{mol}$ photons $\mathrm{m}^{-2} \mathrm{~s}^{-1}$ (high PFD) and $34^{\circ} \mathrm{C}$ during the light period. The air temperature during the 12-h dark periods was either 25,15 or $10^{\circ} \mathrm{C}$. During one treatment $\left(34 / 10^{\circ} \mathrm{C}\right.$, high PFD) the soil temperature was maintained at $25^{\circ} \mathrm{C}$ for the entire experimental period. Data are means $\pm \operatorname{SD}(n=3)$.

dark period (table II). Expressed on a $\chi^{2}$ basis, $P S_{\max }$ was lower for plants cultivated at medium PFD and night temperatures of $10^{\circ}$ or $15^{\circ} \mathrm{C}$ than for those cultivated at $25^{\circ} \mathrm{C}$ night temperature. Differences in $P S_{\max }$ were less pronounced for plants grown under high light conditions. For all treatments similar values for the quantum yield of photosynthetic $\mathrm{O}_{2}$ evolution $(0.092-0.107)$ and for $F_{V} / F_{\mathrm{M}}(0.789-0.811)$ were determined. $P S_{\max }$ (expressed on an area basis), $\varnothing$ and $F_{V^{\prime}}$ $F_{M}$ were little or not affected by keeping the soil temperature constant.

Water potentials and turgor pressures, measured at the end of the dark period of $d 14$, decreased with decreasing temperatures during the dark period (table III). For example, a water po-

Table II. Photosynthetic capacity $\left(P S_{\max } ; \mu \mathrm{mol} \mathrm{O} \mathrm{O}^{-2} \mathrm{~s}^{-1}\right.$ or $\left.\mu \mathrm{mol} \mathrm{O} \mathrm{O}_{2} \mathrm{mg} \mathrm{Chl}^{-1} \mathrm{~s}^{-1}\right)$, quantum yield $\left(\varnothing ; \mathrm{mol} \mathrm{O}_{2} \mathrm{~mol}^{-1}\right.$ photons), and $F_{\mathrm{V}} / F_{\mathrm{M}}$ of third foliar leaves of Gossypium hirsutum.

\begin{tabular}{|c|c|c|c|c|c|c|c|}
\hline \multicolumn{2}{|c|}{$\mathrm{O}_{2}$ evolution and } & \multicolumn{2}{|l|}{ Medium PFD } & \multicolumn{4}{|c|}{ High PFD } \\
\hline & $33 / 10^{\circ} \mathrm{C}$ & $33 / 15^{\circ} \mathrm{C}$ & $33 / 25^{\circ} \mathrm{C}$ & $\begin{array}{l}34 / 10^{\circ} \mathrm{C} \\
25^{\circ} \mathrm{C} \text { soil }\end{array}$ & $34 / 10^{\circ} \mathrm{C}$ & $34 / 15^{\circ} \mathrm{C}$ & $34 / 25^{\circ} \mathrm{C}$ \\
\hline $\begin{array}{l}P S_{\max } \\
\text { (area basis) } \\
\text { (Chl basis) }\end{array}$ & $\begin{array}{l}48.44 \pm 4.55 \\
10.15\end{array}$ & $\begin{array}{l}46.26 \pm 4.37 \\
10.75\end{array}$ & $\begin{array}{l}49.02 \pm 5.77 \\
15.44\end{array}$ & $\begin{array}{l}65.19 \pm 4.79 \\
11.66\end{array}$ & $\begin{array}{l}59.11 \pm 2.00 \\
13.70\end{array}$ & $\begin{array}{l}69.89 \pm 2.68 \\
16.12\end{array}$ & $\begin{array}{l}53.26 \pm 1.75 \\
15.97\end{array}$ \\
\hline$\varnothing$ & $0.106 \pm 0.003$ & $0.103 \pm 0.003$ & $0.106 \pm 0.004$ & $0.092 \pm 0.000$ & $0.103 \pm 0.008$ & $0.107 \pm 0.003$ & $0.102 \pm 0.004$ \\
\hline$F_{V} / F_{M}$ & $0.793 \pm 0.006$ & $0.807 \pm 0.006$ & $0.811 \pm 0.010$ & $0.797 \pm 0.004$ & $0.789 \pm 0.005$ & $0.794 \pm 0.023$ & $0.796 \pm 0.017$ \\
\hline
\end{tabular}

Plants were grown for 2 wk either at $1000-1100 \mu \mathrm{mol}$ photons $\mathrm{m}^{-2} \mathrm{~s}^{-1}$ (medium PFD) and $33^{\circ} \mathrm{C}$ or at $1800-2000 \mu \mathrm{mol}$ photons $\mathrm{m}^{-2} \mathrm{~s}^{-1}$ (high PFD) and $34^{\circ} \mathrm{C}$ during the light period. The air temperature during the 12 -h dark period was either 25,15 or $10^{\circ} \mathrm{C}$. During one treatment $\left(34 / 10^{\circ} \mathrm{C}\right.$, high PFD) the soil temperature was maintained at $25^{\circ} \mathrm{C}$ for the entire experimental period. Samples were taken at the end of the dark period of $d$ 14. Data are means \pm SD $(n=3-6)$. 
Table III. Leaf water status of third foliar leaves of Gossypium hirsutum.

\begin{tabular}{|c|c|c|c|c|c|c|c|}
\hline \multirow[t]{2}{*}{$\begin{array}{l}\text { Leaf water status } \\
(M P a)\end{array}$} & \multicolumn{3}{|c|}{ Medium PFD } & \multicolumn{4}{|c|}{ High PFD } \\
\hline & $33 / 10^{\circ} \mathrm{C}$ & $33 / 15^{\circ} \mathrm{C}$ & $33 / 25^{\circ} \mathrm{C}$ & $\begin{array}{r}34 / 10^{\circ} \mathrm{C} \\
25^{\circ} \mathrm{C} \text { soil }\end{array}$ & $34 / 10^{\circ} \mathrm{C}$ & $34 / 15^{\circ} \mathrm{C}$ & $34 / 25^{\circ} \mathrm{C}$ \\
\hline Water potential & $-0.84 \pm 0.14$ & $-0.71 \pm 0.10$ & $-0.41 \pm 0.05$ & $-0.66 \pm 0.08$ & $-0.76 \pm 0.14$ & $-0.63 \pm 0.09$ & $-0.39 \pm 0.03$ \\
\hline $\begin{array}{l}\text { Osmotic pressure } \\
\text { Estimated turgor }\end{array}$ & $1.34 \pm 0.13$ & $1.32 \pm 0.14$ & $1.16 \pm 0.06$ & $1.59 \pm 0.09$ & $1.25 \pm 0.18$ & $1.37 \pm 0.14$ & $1.08 \pm 0.04$ \\
\hline pressure & $0.50 \pm 0.17$ & $0.62 \pm 0.07$ & $0.75 \pm 0.03$ & $0.93 \pm 0.08$ & $0.50 \pm 0.08$ & $0.74 \pm 0.21$ & $0.69 \pm 0.05$ \\
\hline
\end{tabular}

Plants vere grown for 2 wk either at $1000-1100 \mu$ mol photons $\mathrm{m}^{-2} \mathrm{~s}^{-1}$ (medium PFD) and $33^{\circ} \mathrm{C}$ or at $1800-2000 \mu \mathrm{mol}$ photons $\mathrm{m}^{-2} \mathrm{~s}^{-1}$ (high PFD) and $34{ }^{\circ} \mathrm{C}$ during the light period. The air temperature during the 12 -h dark period was 25,15 or $10^{\circ} \mathrm{C}$. During one treatment $\left(34 / 10^{\circ} \mathrm{C}\right.$, hight $\left.\mathrm{PFD}\right)$ the soil temperature was maintained at $25^{\circ} \mathrm{C}$ for the entire experimental period. Samples were taken at the end of the dark period of day 14 . Data are means $\pm \operatorname{SD}(n=5-6)$.

tential of $-0.41 \mathrm{MPa}$ was determined for plants grown at $33 / 25^{\circ} \mathrm{C}$ and medium PFD, while plants cultivated at $33 / 10^{\circ} \mathrm{C}$ showed a water potential of $-0.84 \mathrm{MPa}$ after $14 \mathrm{~d}$ under these conditions. Keeping the soil temperature at a constant $25^{\circ} \mathrm{C}$ resulted in an increase in leaf turgor pressure, measured at the end of the dark period, from 0.50 to $0.93 \mathrm{MPa}$. This was mainly the consequence of an increase in the osmotic pressure.

Chlorophyll content on a leaf area basis was higher at temperatures of $10^{\circ}$ and $15^{\circ} \mathrm{C}$ during the dark period than at $25^{\circ} \mathrm{C}$ (table IV). The Chl/ Car ratio decreased slightly with increasing temperatures during the dark period. Keeping the soil temperature at a constant $25^{\circ} \mathrm{C}$ resulted in in- creased chlorophyll and carotenoid contents on a leaf area basis. This was partially due to the increase in specific leaf weight.

\section{Effects of soil temperature on plants grown at different air temperatures during the light period}

To further investigate the impact of soil temperature on plant performance, cotton seedlings were cultivated at either an air temperature of $20^{\circ} \mathrm{C}$ and medium PFD or at $24^{\circ}$ or $34^{\circ} \mathrm{C}$ and high PFD. The air temperature during the 12-h dark periods was kept at $25^{\circ} \mathrm{C}$ in all treatments.

Table IV. Pigment contents of third foliar leaves of Gossypium hirsutum.

\begin{tabular}{|c|c|c|c|c|c|c|c|}
\hline \multirow{2}{*}{$\begin{array}{l}\text { Pigments } \\
\left(\mu g \mathrm{~cm}^{-2}\right)\end{array}$} & \multicolumn{3}{|c|}{ Medium PFD } & \multicolumn{4}{|c|}{ High PFD } \\
\hline & $33 / 10^{\circ} \mathrm{C}$ & $33 / 15^{\circ} \mathrm{C}$ & $33 / 25^{\circ} \mathrm{C}$ & $\begin{array}{r}34 / 10^{\circ} \mathrm{C} \\
25^{\circ} \mathrm{C} \text { soil }\end{array}$ & $34 / 10^{\circ} \mathrm{C}$ & $34 / 15^{\circ} \mathrm{C}$ & $34 / 25^{\circ} \mathrm{C}$ \\
\hline $\mathrm{Chl}$ & $47.75 \pm 2.46$ & $43.02 \pm 1.63$ & $31.76 \pm 1.66$ & $55.92 \pm 2.29$ & $43.16 \pm 2.97$ & $43.37 \pm 2.63$ & $33.36 \pm 2.14$ \\
\hline Car & $10.03 \pm 0.61$ & $9.51 \pm 0.39$ & $7.68 \pm 0.55$ & $13.33 \pm 0.24$ & $10.02 \pm 1.29$ & $10.12 \pm 0.91$ & $9.29 \pm 0.66$ \\
\hline Chl/Car & 4.76 & 4.52 & 4.13 & 4.20 & 4.31 & 4.29 & 3.59 \\
\hline
\end{tabular}

Plants were grown for $2 \mathrm{wk}$ at $1000-1100 \mu \mathrm{mol}$ photons $\mathrm{m}^{-2} \mathrm{~s}^{-1}$ (medium PFD) and $33^{\circ} \mathrm{C}$ or at $1800-2000 \mu \mathrm{mol}$ photons $\mathrm{m}^{-2} \mathrm{~s}^{-1}$ (high PFD) and $34^{\circ} \mathrm{C}$ during the light period. The air temperature during the $12-\mathrm{h}$ dark period was either 25,15 or $10^{\circ} \mathrm{C}$. During one treatment $\left(34 / 10^{\circ} \mathrm{C}\right.$, high PFD) the soil temperature was maintained at $25^{\circ} \mathrm{C}$ for the entire experimental period. Samples were taken at the end of the dark period of $d 14$. Data are means $\pm \operatorname{SD}(n=5-6)$. 
The soil temperature was maintained at either $20^{\circ}$ or $30^{\circ} \mathrm{C}$ throughout the 2 -wk cultivation periods. Maintaining the soil temperature constantly at $30^{\circ} \mathrm{C}$ instead of $20^{\circ} \mathrm{C}$ resulted in a $47-55 \%$ increase in total dry weight for plants grown under high PFD and $24 / 25^{\circ} \mathrm{C}$ or $34 / 25^{\circ} \mathrm{C}$, respectively (table $\mathrm{V}$ ). The total leaf area increased by $58 \%\left(24 / 25^{\circ} \mathrm{C}\right)$ and $86 \%\left(34 / 25^{\circ} \mathrm{C}\right)$ as a result of these 2 treatments. The dry weight ratio of shoot to roots also increased with an increase in soil temperature. For example, at high PFD, 34/ $25^{\circ} \mathrm{C}$ and $20^{\circ} \mathrm{C}$ soil temperature the root dry weight accounted for $21 \%$ of the total plant mass. At a soil temperature of $30^{\circ} \mathrm{C}$ the root dry weight accounted only for $11 \%$. The specific leaf weight was not influenced by the soil temperature.

At growth conditions of medium PFD and 20/ $25{ }^{\circ} \mathrm{C}$ the total plant dry weight increased by $28 \%$ as the constant soil temperature increased from $20^{\circ}$ to $30^{\circ} \mathrm{C}$. The shoot/root ratio was nearly the same for both treatments (table V)).

In contrast to the marked changes in growth characteristics that were evident as a result of lower soil temperatures, the values for $F_{\mathrm{V}} / F_{\mathrm{M}}$ and pigment contents (table $\mathrm{VI}$ ) depended mainly on the conditions applied to the shoot and were unaffected by the soil temperature. Similar to the finding of a previous study (Winter and Königer, 1991) chlorophyll and carotenoid contents markedly decreased at air temperatures of $24^{\circ}$ and $20^{\circ} \mathrm{C}$ in comparison to $34^{\circ} \mathrm{C}$, probably owing to photooxidative processes.

\section{DISCUSSION}

Recent investigations revealed that in the long term, air temperatures of $25^{\circ}$ and $20^{\circ} \mathrm{C}$ applied to cotton plants during the light periods may result in impaired photosynthetic performance, photooxidation and in growth reductions, especially at light intensities close to full sunlight (Königer and Winter, 1991; Winter and Königer, 1991). The experiments described in this paper show that when low temperatures are applied during the dark period $\left(15^{\circ}\right.$ or $\left.10^{\circ} \mathrm{C}\right)$, cotton plants also experience drastic reductions in growth. These reductions, however, were not accompanied by inhibitions of photosynthetic $\mathrm{O}_{2}$ evolution (on an area basis) or decreases in $F_{\mathrm{V}} / F_{\mathrm{M}}$. Thus, even temperatures as low as $10^{\circ} \mathrm{C}$ during the dark period do not predispose cotton to high light stress during the following light period. Lowering the temperatures during the light period with high light intensities just slightly below $30^{\circ} \mathrm{C}$ resulted

Table V. Growth characteristics of Gossypium hirsutum.

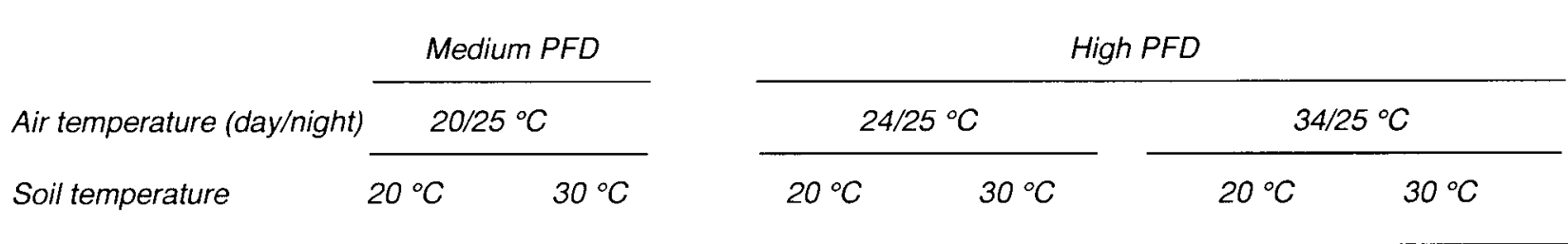

\section{Growth characteristics}

Shoot plus roots

\begin{tabular}{|c|c|c|c|c|c|c|}
\hline$(\mathrm{g} \mathrm{DW})$ & $2.50 \pm 0.41$ & $3.21 \pm 0.91$ & $3.97 \pm 0.30$ & $5.84 \pm 1.73$ & $7.31 \pm 1.14$ & $11.33 \pm 1.83$ \\
\hline Shoot (g DW) & $2.18 \pm 0.36$ & $2.82 \pm 0.78$ & $3.39 \pm 0.16$ & $5.20 \pm 1.55$ & $5.81 \pm 0.81$ & $10.11 \pm 1.55$ \\
\hline Roots (g DW) & $0.32 \pm 0.05$ & $0.40 \pm 0.16$ & $0.58 \pm 0.14$ & $0.60 \pm 0.19$ & $1.50 \pm 0.34$ & $1.22 \pm 0.29$ \\
\hline Shoot/root $\left(\mathrm{g} \mathrm{g}^{-1}\right)$ & 6.81 & 7.07 & 5.84 & 8.67 & 3.87 & 8.29 \\
\hline Leaves (g DW) & $1.59 \pm 0.23$ & $2.20 \pm 0.60$ & $2.44 \pm 0.01$ & $3.93 \pm 1.16$ & $4.07 \pm 0.68$ & $7.27 \pm 1.10$ \\
\hline Stems (g DW) & $0.59 \pm 0.13$ & $0.61 \pm 0.18$ & $0.95 \pm 0.16$ & $1.27 \pm 0.40$ & $1.74 \pm 0.13$ & $2.84 \pm 0.45$ \\
\hline Leaf/stem $\left(\mathrm{g} \mathrm{g}^{-1}\right)$ & 2.69 & 3.59 & 2.57 & 3.09 & 2.34 & 2.56 \\
\hline Leaf area total $\left(\mathrm{cm}^{2}\right)$ & $401 \pm 27$ & $535 \pm 121$ & $544 \pm 31$ & $860 \pm 221$ & $741 \pm 126$ & $1381 \pm 113$ \\
\hline $\begin{array}{l}\text { Spec leaf weight } \\
\text { mg DW } \mathrm{cm}^{-2} \text { ) }\end{array}$ & 3.97 & 4.11 & 4.49 & 4.57 & 5.49 & 5.26 \\
\hline
\end{tabular}

Plants were cultivated for $2 \mathrm{wk}$ at $1000-1100 \mu \mathrm{mol}$ photons $\mathrm{m}^{-2} \mathrm{~s}^{-1}$ (medium PFD) or $1800-2000 \mu \mathrm{mol}$ photons $\mathrm{m}^{-2} \mathrm{~s}^{-1}$ (high PFD). The air temperature was $20^{\circ} \mathrm{C}$ at medium PFD and $24^{\circ}$ or $34^{\circ} \mathrm{C}$ at high PFD. The temperature during the 12-h dark period was $25^{\circ} \mathrm{C}$ in all experiments. Soil temperature was kept at $20^{\circ}$ or $30^{\circ} \mathrm{C}$ throughout the experimental period. The data are means \pm $\mathrm{SD}(n=3-4)$. 
Table VI. Pigment contents and fluorescence values $\left(F_{V} / F_{M}\right)$ of the third foliar leaves of Gossypium hirsutum.

\begin{tabular}{|c|c|c|c|c|c|c|}
\hline \multirow{3}{*}{$\begin{array}{l}\text { Air temperature } \\
\text { (day/night) } \\
\text { Soil temperature }\end{array}$} & \multicolumn{2}{|c|}{ Medium PFD } & \multicolumn{4}{|c|}{ High PFD } \\
\hline & \multicolumn{2}{|c|}{$20 / 25^{\circ} \mathrm{C}$} & \multicolumn{2}{|l|}{$24 / 25^{\circ} \mathrm{C}$} & \multicolumn{2}{|l|}{$34 / 25^{\circ} \mathrm{C}$} \\
\hline & $20^{\circ} \mathrm{C}$ & $30^{\circ} \mathrm{C}$ & $20^{\circ} \mathrm{C}$ & $30^{\circ} \mathrm{C}$ & $20^{\circ} \mathrm{C}$ & $30^{\circ} \mathrm{C}$ \\
\hline \multicolumn{7}{|l|}{$\begin{array}{l}\text { Pigments, } \\
\text { fluorescence }\end{array}$} \\
\hline $\mathrm{Chl}\left(\mu \mathrm{g} \mathrm{cm}^{-2}\right)$ & $9.74 \pm 0.53$ & $9.62 \pm 0.25$ & $11.90 \pm 3.79$ & $9.07 \pm 2.41$ & $33.75 \pm 2.13$ & $31.21 \pm 2.79$ \\
\hline $\operatorname{Car}\left(\mu \mathrm{g} \mathrm{\textrm {cm } ^ { - 2 }}\right)$ & $4.50 \pm 0.54$ & $4.60 \pm 0.55$ & $5.80 \pm 0.80$ & $4.61 \pm 0.81$ & $9.55 \pm 0.61$ & $8.28 \pm 0.25$ \\
\hline $\mathrm{Chl} / \mathrm{Car}$ & 2.16 & 2.09 & 2.05 & 1.97 & 3.53 & 3.77 \\
\hline$F_{\mathrm{V}} / F_{\mathrm{M}}$ & $0.732 \pm 0.040$ & $0.710 \pm 0.040$ & $0.745 \pm 0.015$ & $0.733 \pm 0.024$ & $0.803 \pm 0.004$ & $0.812 \pm 0.005$ \\
\hline
\end{tabular}

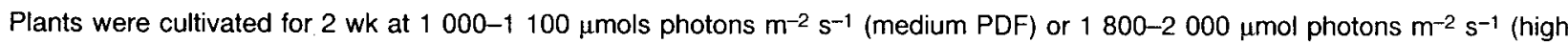
PFD). The air temperature was $20^{\circ} \mathrm{C}$ at medium PFD and $24^{\circ}$ or $34^{\circ} \mathrm{C}$ at high PFD. The air temperature during the $12-\mathrm{h}$ dark period was $25^{\circ} \mathrm{C}$ in all experiments. The soil temperature was kept at $20^{\circ}$ or $30^{\circ} \mathrm{C}$ throughout the experimental period. The data are means $\pm \operatorname{SD}(n=3-4)$.

in growth reductions (Winter and Königer, 1991) as severe as those caused by lowering the night temperature from $25^{\circ}$ to $10^{\circ} \mathrm{C}$. The finding of Patterson and Mortensen (1985), that growth in common crupina reacted more sensitively to changes in temperature during the night than during the day, was probably due to the fact that their plants were exposed to relatively low light intensities $\left(430 \mu \mathrm{mol} \mathrm{m}^{-2} \mathrm{~s}^{-1}\right)$.

Various short-term experiments have revealed that low temperatures can lead to considerable accumulations of carbohydrates in source leaves, which could potentially result in a feedback inhibition of photosynthesis (Azcon-Bieto, 1983; Paul et al, 1990; Stitt, 1991; Brüggemann et al, 1992). For example, exposing rice plants, cultivated at $32 / 22{ }^{\circ} \mathrm{C}$ (light/dark period) for $3 \mathrm{~d}$ to $21 / 10{ }^{\circ} \mathrm{C}$ resulted in reduced $\mathrm{CO}_{2}$ assimilation rates accompanied by an accumulation of carbohydrates (Huang et al, 1989). Marked and sustained increases in carbohydrates were also found in cotton plants exposed for $4 \mathrm{~d}$ to low air temperatures $\left(20^{\circ} \mathrm{C}\right.$ ) during the light period (Königer and Winter, 1992). Thus feedback inhibition may, in principle, have played a role in the results reported here. For example, at the end of the cultivation periods lower values for $P S_{\max }$ expressed on a $\mathrm{chl}$ basis were found in plants grown under lower night temperatures and medium PFD. However, under high light, when in theory the leaves should have higher carbohydrate levels, there were no discernable differences in $P S_{\max }$ even when expressed on a chlorophyll basis. The increases in specific leaf weights seen with decreasing night temperatures reveal the marked influence of temperature on leaf development and are likely to be the basis for the similar rates of $P S_{\max }$ that were seen when they were expressed on an area basis. Keeping the soil temperature at a constant $25^{\circ} \mathrm{C}$ for plants grown at high PFD and $34 / 10^{\circ} \mathrm{C}$ (light/dark period), and thus increasing the sink strength of the plants also did not result in an increase in $P S_{\max }$ at the end of the 2-w k cultivation period. We have therefore concluded that if feedback inhibition developed during the treatment, compensatory effects which overcame it in the long term must have occurred.

Reduced air temperatures during dark $\left(15^{\circ}\right.$, $\left.10^{\circ} \mathrm{C}\right)$ or light periods $\left(20^{\circ}, 24^{\circ} \mathrm{C}\right.$; see Winter and Königer, 1991) resulted in decreases in leaf turgor pressure. This was probably due to an impairment of water uptake rates at these low soil temperatures (Kramer, 1983). A reduction in temperature from 30 to $20^{\circ} \mathrm{C}$ in the root medium has been reported to result in a decrease in the water uptake rate of cotton roots by $40 \%$ (Shirazi et al, 1975; see also Bassiri Rad et al, 1991). Plants cultivated at low soil and/or air temperatures had lower shoot/root ratios than those grown at higher temperatures, indicating that the plants invested more into their root system, which may improve the water uptake. A preferred allocation of photosynthates to the roots under 
low root temperature conditions was also reported for other species (eg oil seed rape: Mc Duff al, 1987).

The experiments reported here have shown that in all cases lower soil and night air temperatures lead to a lower accumulation of biomass. Partial stomatal closure, as a result of temporary water stress, leading to reduced photosynthetic rates under ambient $\mathrm{CO}_{2}$ (Ku et al, 1978; Musser et al, 1983; De Lucia, 1986; De Lucia et al, 1991; Vapaavuori et al, 1992) may be in part responsible for these results. Huang et al (1989) found less severe effects on $\mathrm{CO}_{2}$ assimilation rates in rice at $21 / 10^{\circ} \mathrm{C}$ (light/dark period) when the root temperature was kept at a constant $20^{\circ} \mathrm{C}$ instead of allowing it to follow the air temperature. The authors suggested that this could be partly due to an improvement in the water status of the plants (see also Boyer, 1968; Anderson and Mc Naughton, 1973).

\section{CONCLUSIONS}

We have found that in cotton plants low air temperature during the night and low soil temperatures always lead to severe reductions in growth. There was no evidence that these cool temperatures predisposed the leaves to photoinhibition during the light periods. Evidence was also obtained revealing that the cool night and rhizosphere temperatures influence plant development by altering leaf morphology (increases in specific leaf weight; thicker leaves) and partitioning ratios (greater investment in roots as opposed to shoots).

\section{ACKNOWLEDGMENTS}

This study was supported by the Deutsche Forschungsgemeinschaft (SFB 251, Universität Würzburg). We express our thanks to $M$ Lesch for technical assistance, and $G$ Harris for critical comments on the paper.

\section{REFERENCES}

Anderson JE, Mc Naughton SJ (1973) Effects of low soil temperature on transpiration, photosynthesis, leaf relative water content, and growth among elevationally diverse plant populations. Ecology 54, 1220-1233

Azcon-Bieto $J(1983)$ Inhibition of photosynthesis by carbohydrates in wheat leaves. Plant Physiol 73, 681-686
Bassiri Rad H, Radin JW, Matsuda K (1991) Temperature-dependent water and ion properties of barley and sorghum roots. Plant Physiol 97, 426-432

Boyer JS (1968) Relationship of water potential to growth of leaves. Plant Physiol 43, 1056-1062

Brüggemann W, Van der Kooij TAW, Van Hasselt PR (1992) Longterm chilling of young tomato plants under low light and subsequent recovery. II. Chlorophyll fluorescence, carbon metabolism and activity of ribulose-1,5-bisphosphate carboxylase/oxygenase. Planta 186, 179-187

De Lucia EH (1986) Effects of low root temperature on net photosynthesis, stomatal conductance, and carbohydrate concentration in Engelmann spruce (Picea engelmannii Parry ex Engelm) seedlings. Tree Physiol 2, 143-154

De Lucia EH, Day TA, Öquist G (1991) The potential for photoinhibition of Pinus sylvestris $\mathrm{L}$ seedlings exposed to high light and low soil temperature. $J$ Exp Bot 42, 611-617

Downton J, Slatyer RO (1972) Temperature dependence of photosynthesis in cotton. Plant Physiol 50, 518-522

Gong H, Nielsen S (1989) Effect of temperature on photoinhibition of photosynthesis, recovery, and turnover of the 32-kDa chloroplast protein in Lemna gibba. J Plant Physiol 135, 9-14

Greer DH, Laing WA, Kipnis T (1988) Photoinhibition of photosynthesis in intact kiwifruit (Actinidia deliciosa) leaves: effect of temperature. Planta 174, 152-158

Huang LK, Wong SC, Terashima I, Zhang X, Lin D-X, Osmond CB (1989) Chilling injury in mature leaves of rice. I. Varietal differences in the effects of chilling on canopy photosynthesis under simulated "dry cold dew wind" conditions experienced in south-east China. Aust J Plant Physiol 16, 321-337

Königer M, Winter K (1991) Carotenoid composition and photon-use efficiency of photosynthesis in Gossypium hirsutum $\mathrm{L}$ grown under conditions of slightly suboptimal leaf temperatures and high levels of irradiance. Oecologia 87, 349-356

Königer M, Winter K (1993) Reduction of photosynthesis in sun leaves of Gossypium hirsutum $L$ under conditions of high light intensities and suboptimal leaf temperatures. agronomie (in press)

Kramer PJ (1983) Water Relations of Plants. Academic Press Inc, NY

Ku SB, Edwards GE, Smith D (1978) Photosynthesis and nonstructural carbohydrate concentrations in leaf blades of Panicum virgatum as affected by night temperature. Can J Bot 56, 63-68

Mc Allister RS, Haderlie LC (1985) Effects of photoperiod and temperature on root bud development and assimilate translocation in Canada thistle (Cirsium arvense). Weed Sci 33, 148-152

Mc Duff JH, Hopper MJ, Wild A, Trim FE (1987) Comparison of the effects of root temperature on nitrate and ammonium nutrition of oil-seed rape (Brassica napus $L$ ) in flowing solution culture. 1 Growth and uptake of nitrogen. J Exp Bot 38, 1 104-1120 
Metzner H, Rau H, Senger H (1965) Untersuchungen zur Synchronisierbarkeit einzelner PigmentmangelMutanten von Chlorella. Planta 65, 186-194

Musser RL, Thomas SA, Wise RR, Peeler TC, Naylor AW (1984) Chloroplast ultrastructure, chlorophyll fluorescence, and pigment composition in chillingstressed soybeans. Plant Physiol 74, 749-754

Ögren E, Öquist G, Hällgren J-E (1984) Photoinhibition of photosynthesis in Lemna gibba as induced by the interaction between light and temperature. I. Photosynthesis in vivo. Physiol Plant 62, 181-186

Patterson DT, Meyer CR, Flint EP, Quimby Jr PC (1979) Temperature responses and potential distribution of itchgrass (Rottboellia exaltata) in the United States. Weed Sci 27, 77-82

Patterson DT, Mortensen DA (1985) Effects of temperature and photoperiod on common crupina (Crupina vulgaris). Weed Sci 33, 333-339

Paul MJ, Lawlor DW, Discroll SP (1990) The effect of temperature on photosynthesis and carbon flux in sunflower and rape. J Exp Bot 41, 547-555

Rosenqvist E, Wingsle G, Ögren E (1991) Photoinhibition of photosynthesis in intact willow leaves in response to moderate changes in light and temperature. Physiol Plant 83, 390-396

Röbbelen G (1957) Untersuchungen an strahleninduzierten Blattfarbmutanten von Arabidopsis thaliana (L). Heyn Z Indukt Abstammungs-Vererbungs/ 88, 189-252

Schleppi P, Soldati A, Keller ER (1990) Photosynthate partitioning in flowering soybeans subjected to cold stress. J Plant Physiol 136, 556-563
Schreiber U, Schliwa U, Bilger W (1986) Continuous recording of photochemical and non-photochemical fluorescence quenching with a new type of modulation fluorometer. Photosynth Res 10, 51-62

Shirazi GA, Stone JF, Croy LI, Todd GW (1975) Changes in root resistance as a function of applied suction, time of day, and root temperature. Physiol Plant 33, 214-218

Stitt $M$ (1991) Rising $\mathrm{CO}_{2}$ levels and their potential significance for carbon flow in photosynthetic cells. Plant Cell Environ 14, 741-762

Vapaavuori EM, Rikala R, Ryyppö A (1992) Effects of root temperature on growth and photosynthesis in conifer seedlings during shoot elongation. Tree Physiol 10, 217-230

West SH (1973) Carbohydrate metabolism and photosynthesis of tropical grasses subjected to low temperature. In: Plant Response to Climate Factors. Proc Uppsala Symp (Slatyer RO, ed) UNESCO, Paris, 165-168

Winter K, Königer M (1991) Dry matter production and photosynthetic capacity in Gossypium hirsutum L under conditions of slightly suboptimum leaf temperatures and high levels of irradiance. Oecologia 87, 190-197

Wong SC (1979) Elevated atmospheric partial pressures of $\mathrm{CO}_{2}$ and plant growth. Oecologia 44, 6874

Zollinger RK, Kells JJ (1991) Effects of soil pH, soil water, light intensity, and temperature on perennial sowthistle (Sonchus arvensis L). Weed Sci 39, 376-384 